\title{
The asymmetric nature of V2: Evidence from learner languages ${ }^{1}$
}

\author{
Marit Westergaard ${ }^{1,2}$, Terje Lohndal ${ }^{2,1} \&$ Artemis Alexiadou $^{3}$ \\ ${ }^{1}$ UiT The Arctic University of Norway, ${ }^{2}$ NTNU Norwegian Univer- \\ sity of Science and Technology, ${ }^{3}$ Humboldt Universität zu Berlin \& \\ ZAS
}

\begin{abstract}
In the field of Germanic linguistics, there has been a long-standing debate as to the question of how to analyze sentences with verb second (V2) word order. In particular, the question has been whether or not subject-initial and non-subject-initial main clause declaratives should receive the same structural analysis. Here we review this debate and provide new evidence from learner languages involving Norwegian. This evidence, we argue, supports an analysis whereby subject-initial main clauses are derived differently than non-subject-initial clauses. We outline this analysis and discuss some consequences.
\end{abstract}

\section{Introduction}

The proper syntactic analysis of V2 word order has been an issue of controversy. In particular, considerable attention has been devoted to whether subject-initial and non-subject-initial clauses can be given a uniform analysis, more specifically whether subject-initial declaratives exhibit verb

1 A version of this paper was presented at the Comparative Germanic Syntax Workshop in Stellenbosch in December 2016, and we would like to thank the audience for helpful comments and discussion. This research was partly funded by a grant from the Research Council of Norway for the project MiMS (Micro-variation in Multilingual Acquisition \& Attrition Situations), project number 250857 (Westergaard) and DFG project AL 554/8-1 (Alexiadou). The topic of this paper is very relevant to Sten's important work in Germanic linguistics, and although our data provide partial evidence against Sten's analysis of V2, we are very happy and honored to present this to him on his $60^{\text {th }}$ birthday.

Ken Ramshøj Christensen, Henrik Jørgensen \& Johanna L. Wood (eds.). 2019.

The Sign of the V-Papers in Honour of Sten Vikner. Dept. of English, School of Communication \& Culture, Aarhus University, pp. 709-733, doi:10.7146/aul.348.121. (C) The author(s). 
movement to a left peripheral head in the clause (C). In this paper, we address this debate from a point of view different from that typically found in the literature. We focus on data from various learner populations, mainly involving Norwegian, including L1, L2/Ln, heritage languages, and urban vernaculars. We make use of these Norwegian data to argue in favor of an asymmetric account of $\mathrm{V} 2$, which means that, unlike non-subject-initial declaratives, subject-initial declaratives do not display verb movement to C. Furthermore, we argue that V2 is non-parametric and emerges as a conspiracy of several factors. The logic of the proposal is that subject-initial and non-subject-initial declaratives behave differently, and crucially, that this difference is due to the placement of the verb. In this paper, the precise position of the verb is not our main concern, rather the difference between the two contexts.

This paper is structured as follows: In Section 2, we discuss some background concerning the symmetric and asymmetric analyses of V2. Section 3 provides a review of relevant data from acquisition and attrition involving Norwegian. We discuss the data and offer concluding remarks in Section 4.

\section{Background}

In this section, we present some relevant background for the analysis of V2 which will serve as a context for the objectives of the present paper. Section 2.1 outlines the symmetric and asymmetric analyses of V2 and their implications. Section 2.2 provides some evidence in favor of the symmetric analysis for Flemish dialects, while Section 2.3 discusses the possibility that languages and even different constituents may vary in terms of whether or not the analysis of subject- and non-subject-initial declaratives are symmetric or asymmetric.

\subsection{Symmetric and asymmetric analyses of $\mathrm{V} 2$}

As is well-known, the analysis of V2 has been hotly debated in the syntactic literature. The main controversy relates to the question of whether subjects as well as other fronted elements (objects and adverbials) occupy the same structural position or not. In other words, is the subject DP Jon in the Norwegian example in (1) situated in the same position as the object DP ost 'cheese' in (2)? 
(1) Norwegian

Jon spiste ost.

Jon ate cheese

'John ate cheese.'

(2) Norwegian

Ost spiste Jon. (non-subject-initial declarative)

Cheese ate Jon

'Cheese, John ate.'

Den Besten (1983) as well as Koopman (1984); Holmberg (1986); Taraldsen (1986); Schwartz \& Vikner (1989); Weerman (1989); Tomaselli (1990); Shlonsky (1994); Holmberg \& Platzack (1995); Vikner (1995); Schwartz \& Vikner (1996); Haegeman (1996); Platzack (1998) and van Craenenbroeck \& Haegeman (2007) adopt the so-called symmetric analysis, according to which both subjects and non-subjects occupy SpecCP. In embedded clauses, according to this analysis, the subject is located lower in the structure, in SpecIP. In contrast, Travis $(1984,1991)$ and Zwart $(1993,1997)$ as well as Rögnvaldsson \& Thráinsson (1990); Diesing (1990) and Sells (2001) adopt an analysis, according to which the subject is situated in SpecIP in both main and embedded clauses. This type of analysis of V2 is referred as asymmetric, as non-subjects occupy SpecCP, a position different from that of subject DPs. ${ }^{2}$

The symmetric and asymmetric analyses are based on different derivations for subject-initial and non-subject-initial declaratives. That is, the two contexts differ in terms of verb movement: The verb is positioned lower in subject-initial declaratives compared to non-subject-initial declaratives. A straightforward option is then to associate the difference with verb movement to different domains (Platzack 2001; Grohmann 2003). That would provide the following structures, setting aside potential additional argument-introducing functional projections (see, among many others, Lohndal 2014 and Alexiadou, Anagnostopoulou \& Schäfer 2015 for discussion).

2 Other alternatives involve a) viewing I and $\mathrm{C}$ as form-matching categories, as in e.g., Haider (1988); Müller \& Sternefeld (1993); cf. the notion of Coalescence in Hsu (2016); b) remnant movement of the $v \mathrm{P}$, as in Müller (2004); see also Nilsen (2003) and c) reprojection in the landing site of the verb, e.g., Fanselow (2001, 2004, 2009), see also Bierwisch (1963); Thiersch (1978); Ackema, Neeleman \& Weerman (1993); Koeneman (1995, 2000); Bury (2000). 
(3) Subject-initial declaratives:

$\left[{ }_{\mathrm{CP}}\left[{ }_{\mathrm{C}} \mathrm{C}\right]\left[_{\mathrm{IP}}\right.\right.$ subject $\left.\left.[\mathrm{I} \mathrm{V}]\left[_{\mathrm{vP}} \mathrm{t}_{\text {subject }} \mathrm{t}_{\mathrm{V}} \ldots\right]\right]\right]$

(4) Non-subject-initial declaratives:

$\left[{ }_{\mathrm{CP}} \mathrm{XP}\left[{ }_{\mathrm{C}} \mathrm{V}\right]\left[_{\mathrm{IP}}\right.\right.$ subject $\left.\left.\left[\mathrm{t}_{\mathrm{V}}\right]\left[_{\mathrm{vP}} \mathrm{t}_{\text {subject }} \mathrm{t}_{\mathrm{V}} \ldots\right]\right]\right]$

In (3), the verb moves from $\mathrm{V}$ to $\mathrm{I}$, and in (4), the verb moves from $\mathrm{V}$ to $\mathrm{C}$, via the I position, clearly demonstrating two different structural representations. However, an asymmetric analysis does not necessarily mean a commitment to the structures in (3) and (4). An alternative cartographic implementation (cf. Rizzi 1997; Cinque 1999; see also Branigan 1996) would be to argue that, in fact, the verb moves to the left periphery in both cases, but crucially to different heads in the left periphery. For example, subject-initial declaratives may have the verb in a low left peripheral position, whereas non-subject-initial declaratives have the verb in a higher left peripheral position.

A symmetric analysis capitalizes on what we may label 'economy of specification'. Roberts (2007: 274), and Biberauer \& Roberts (2012, 2015) argue that a child seeks to postulate a grammar which minimizes the number of distinct formal specifications. This perspective would therefore support the symmetric analysis, since it would involve fewer distinctly specified functional heads. A different perspective would focus on the acquisition process and the input evidence available to children when acquiring verb placement. As noted in Holmberg (2015: 364), the symmetric analysis creates an acquisition problem: How would the child ever detect evidence in favor of movement to $\mathrm{C}$, given that this movement does not have any PF effects? Languages that supposedly have V-to-I-to-C in subject-initial main clauses but only V-to-I in embedded clauses may be unlearnable due to lack of overt evidence. This resonates with findings from acquisition, showing that children typically do not generalize across linguistic contexts, e.g., they do not assume that different clause types display the same kinds of movement operations. Rather, when they make mistakes, these mistakes are generally due to economy (Snyder 2007; Westergaard 2009a, 2014), in that they produce less movement than what is found in the input. Thus, rather than economy of specification, 'economy of movement' appears to be the relevant guiding principle. As argued in Westergaard \& Bentzen (2007), an economy principle is operative in the acquisition process, causing children to move the verb only as high in the structure as there is evidence for in the input. Generalizing this based on the assumption 
that there is continuity across the lifespan, it seems natural to assume that monolingual adults also have the same economy principle, causing them to distinguish subject-initial from non-subject-initial declaratives. There is also significant variation in the adult language in terms of how this distinction is implemented into the grammar, i.e., which functional projection the verb moves to, as seen in Bentzen (2014); Wiklund et al. (2009); Haegeman \& Greco (2018) and Lohndal, Westergaard \& Vangsnes (in press). These different realizations are presumably related to the complex nature of the V2 phenomenon, an issue we return to in section 4.

The symmetric and asymmetric analyses make different predictions. As Holmberg (2015: 364) points out, the asymmetric analysis predicts similarity between subject-initial main and embedded clauses, and no similarity between subject-initial and non-subject-initial main clauses. The reason is that the former two have similar structural representations on the asymmetric analysis, unlike the latter. A way to test this prediction would involve extraction out of embedded V2 clauses. As Holmberg (1986: 109115) and Vikner (1995: 108-110) have shown, extraction out of embedded V2 clauses is prohibited or at least much more restricted than in the case of embedded non-V2 clauses. Sentence (5) illustrates that when a high verb precedes negation in the embedded clause, extraction is disallowed, whereas if the finite verb follows negation, extraction is possible.

(5) Swedish (Holmberg 1986: 111)

$\begin{array}{lllll}\text { Vilken fest }{ }_{\mathrm{i}} \text { sa } & \text { hun } & \text { [att } & \text { vi (*behöver) inte } \\ \text { which party said } & \text { she } & \text { that } & \text { we need not } \\ \text { (behöver) köpa } & \text { roliga } & \text { hattar } & \left.\text { til } \mathrm{t}_{\mathrm{i}}\right] \text { ? } \\ \text { need } & \text { buy funny } & \text { hats } & \text { for }\end{array}$

'Which party did she say that we don't need to buy funny hats for?'

On the symmetrical analysis, $\mathrm{SpecCP}$ is always filled by a constituent, be it a subject or a non-subject. Since SpecCP is assumed to be the escape hatch for extraction, this entails that extraction would be predicted to be impossible in both subject-initial and non-subject-initial clauses. The asymmetrical analysis, on the other hand, only has SpecCP filled by a constituent in non-subject-initial clauses, which then predicts extraction to be possible in subject-initial clauses. Importantly, extraction data from Norwegian confirm the predictions of the asymmetric analysis. Sentence (6) shows that argument extraction out of a non-subject-initial V2 clause is impossible in Norwegian, while (7) shows that extraction out of a subject- 
initial clause is indeed possible (Hrafnbjargarson, Bentzen \& Wiklund 2010: 303-4). Thus, these data are in line with the predictions made by the asymmetrical analysis, since this analysis holds that there is an escape hatch in subject-initial declaratives.

(6) Norwegian

a. ${ }^{*}$ Hvem $_{\mathrm{i}}$ sa han at denne boka hadde $\mathrm{t}_{\mathrm{i}}$ ikke gitt Kari? who said hethat this book.DEF had not given Kari

b. ${ }^{*}$ Hvem $_{\mathrm{i}}$ sa han at denne boka hadde han ikke gitt $\mathrm{t}_{\mathrm{i}}$ ? whom said he that this book.DEF had he not given

\section{(7) Norwegian}

a. Hvem ${ }_{i}$ sa han at $t_{i}$ kunne ikke synge denne sangen? who said he that could not sing this song.DEF

b. $\mathrm{Hva}_{\mathrm{i}}$ sa han at han ikke kunne synge $\mathrm{t}_{\mathrm{i}}$ ? what said he that he not could sing

In the next section, we turn to a different argument, demonstrating that in other varieties, the symmetric analysis is required.

\subsection{An argument in favor of the symmetric analysis}

Zwart (1997: 207-223) offers a comprehensive discussion of the traditional empirical arguments involved in adjudicating between the symmetric and asymmetric analysis of V2. In a more recent contribution, van Craenenbroeck \& Haegeman (2007) concede that "[f]inding empirical evidence in favor of either approach is not easy". However, they argue that the logic of the argument should be as follows: Consider a fixed position $\mathrm{X}$ at the border between TP and CP. The symmetrical and asymmetrical analyses make different predictions: The former holds that the verb should move to the $\mathrm{C}$-domain, crossing and thereby preceding the element $\mathrm{X}$. The latter makes the prediction that the verb should move to the $\mathrm{T}$ domain and thus follow X. Schematic illustrations are provided in (8) (van Craenenbroeck \& Haegeman 2007: 169).

(8) a. $\quad\left[{ }_{\mathrm{CP}}\left[{ }_{\mathrm{C}} \mathrm{C}\right] \mathrm{X}\left[_{\mathrm{TP}}\right.\right.$ subject $\left.\left.\left[{ }_{\mathrm{T}} \mathrm{V}\right]\left[_{\mathrm{vP}} \ldots\right]\right]\right]$

b. $\quad\left[{ }_{\mathrm{CP}}\right.$ subject $\left.\left[\mathrm{C}_{\mathrm{C}} \mathrm{V}\right] \mathrm{X}\left[_{\mathrm{TP}} \mathrm{t}_{\text {subject }}\left[_{\mathrm{T}} \mathrm{t}_{\mathrm{V}}\right]\left[{ }_{\mathrm{VP}} \ldots\right]\right]\right]$ 
Van Craenenbroeck \& Haegeman then provide evidence from two phenomena that support the symmetric analysis: The object clitic $t$ in the Brabant dialect of Wambeek in Belgium and the particle tet in the West Flemish dialect of Lapscheure in Belgium. Let us consider each of these in turn.

The object clitic $t$ occupies a fixed position on the border between the T and $\mathrm{C}$ domains and, as such, it qualifies as the diagnostic element $\mathrm{X}$. This clitic follows the inflected verb and precedes the subject in non-subjectinitial main clauses, while it invariably follows both the subject and the finite verb in subject-initial declaratives. This is illustrated in (9)-(10), from van Craenenbroeck \& Haegeman (2007: 169, 171).

(9) Dutch, Brabant dialect

Nou wenj-t Marie al.

now knows-it Marie already

'Now, Marie already knows it.'

(10) Dutch, Brabant dialect

a. Marie wenj-t al.

Marie knows-it already

b. *Marie $\mathbf{t}$ wenj al.

Marie it knows already

The second example involves the particle tet in the West Flemish dialect of Lapscheure (Haegeman 1986). The particle has a fixed position: In embedded clauses, it occurs to the immediate right of the complementizer and to the immediate left of the subject DP, as shown in (11) (van Craenenbroeck \& Haegeman 2007: 174).

(11) Dutch, Lapscheure dialect

Kpeinzen dat tet Valère da nie goa willen doen.

I.think that TET Valère that not go want do

'I think that Valère won't want to do that.'

Given this, the crucial testing ground then becomes the following data set (van Craenenbroeck \& Haegeman 2007: 175). 


\section{Dutch, Lapscheure dialect}

a. Morgen goa tet Valère da niet willen doen. tomorrow goes TET Valère that not want do

'Valère won't want to do that tomorrow.'

b. Valère goa tet da morgen nie willen doen. Valère goes TET that tomorrow not want do

c. *Valère tet goa da morgen nie willen doen. Valère TET goes that tomorrow not want do

Sentence (12a) is a non-subject-initial main clause, and tet precedes the subject and follows the finite verb. However, the crucial comparison involves (12b) and (12c), which demonstrate that the particle obligatorily follows the finite verb also in subject-initial main clauses. Van Craenenbroeck \& Haegeman argue that the asymmetric analysis would have predicted that the particle should precede the finite verb if the finite verb is in the T domain.

The evidence reviewed here strongly suggests that the verb moves to the $\mathrm{C}$ domain in both subject- and non-subject-initial main clauses in the Brabant and Lapscheure dialects. Crucially, in our view, there is evidence for this in the input, which means that children would acquire this verb movement based on the primary linguistic data.

\subsection{Differences across languages}

For Dutch the debate between the symmetric and asymmetric analysis has centered on data from different dialects. As Haegeman \& Greco (2018: 47) point out: "[...] one option not explored at the time of the earlier debate was that both derivations were available and that there might be microvariation in the derivation of subject-initial V2." Following Postma (2011), they argue that different dialects of Dutch rely on how subject-initial declaratives are derived: some move the subject to the same position as non-subjects (symmetric), and others move the subject to a lower position than non-subjects (asymmetric). A somewhat similar proposal is defended by Mikkelsen (2015), who argues that the derivation of subject-initial V2 may vary language-internally depending on the information structure of the subject: Information-structurally distinguished initial subjects are in the CP domain, whereas initial subjects that are information-structurally undistinguished are in the TP domain. 
The present paper will side with Mikkelsen (2015) and Haegeman \& Greco (2018) in defending a variational perspective: Varieties differ in terms of whether the symmetric or asymmetric analysis of V2 is correct, and the crucial factor is whether there is evidence in the input for verb movement to a higher position. Previous accounts have mostly relied on monolingual data and arguments of theoretical elegance (economy conditions such as a ban on vacuous movement). However, as Holmberg (2015) points out, evidence from acquisition is paramount, and we would like to claim that this evidence ought to be more prominent in order to solve the controversy surrounding the analysis of subject-initial V2 clauses. While the V2 phenomenon has been studied extensively in the acquisition literature, there is relatively sparse data focusing on a possible difference between subject- and non-subject-initial declaratives. In what follows, we review data from learner varieties of Norwegian, providing evidence from L1 and L2 acquisition as well as heritage language bilingualism and ethnolects.

\section{Data from acquisition and attrition}

\subsection{L1 acquisition}

We start by considering evidence from L1 acquisition, where V2 word order has been attested from the earliest possible utterances in a number of languages, e.g., German (Clahsen 1986; Poeppel \& Wexler 1993), Dutch (Jordens 1990) or Swedish (Santelmann 1995; Waldmann 2008). The examples in (13) and (14) are from Norwegian, showing that targetconsistent V2 is found before the age of two in both subject- and nonsubject-initial declaratives (Westergaard 2009a).

\section{(13) Norwegian}

så tegne $\boldsymbol{e}$ mamma. (Ina 1;10.4)

then draw.PRES I mommie

'Then I draw mommie.'

\section{(14) Norwegian}

ho mamma er ikke på jobb. (Ole 1;10.0)

DET MOm be.PRES not on work

'Mom is not at work.'

The question is where the verb has moved to in sentence (14) - to the same position as in (13), i.e. the $\mathrm{C}$ head, or only to the position above 
negation (I). If the former, then we could argue that children would be generalizing from one context to another, if the latter, their production would be governed by a principle of economy; i.e., they would not move an element any higher in the structure than there is evidence for in the input. We now consider which option is the more plausible one, by looking at typical non-target-consistent production in child language.

As argued in much work on L1 acquisition, young children are characterized as conservative learners, generally producing errors of omission, rather than errors of commission (Snyder 2007). ${ }^{3}$ For syntactic movement operations, this means that we typically find lack of movement in early data, e.g., non-V2 in non-subject-initial declaratives, as in examples (15)-(16) from Norwegian and Swedish respectively. Importantly, overgeneralization of V2 to contexts that do not display this word order in the target language is generally non-attested.

(15) Norwegian (Westergaard 2004: 117)

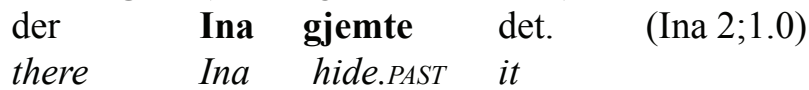

'There Ina hid it.'

Target: Der gjemte Ina det.

(16) Swedish (Waldmann 2012: 344)

sen den skulle gå hem. (Tea 2;11.07)

then it would go home

'Then it would go home.'

Target: Sen skulle den gå hem.

This can also be shown for subject-auxiliary inversion in English child language. While non-inversion is sometimes attested in the production of young children, as illustrated in (17), over-extension of inversion to other contexts, e.g., from questions to declaratives or from auxiliaries to lexical verbs, is virtually non-existent in child data (Westergaard 2009b, Radford 1992).

3 This does not mean that other types of errors do not occasionally occur, e.g., medial wh-elements in complex questions in English and other languages (e.g., Thornton 1990; Lohndal 2010). However, the more common non-target-consistent production, as illustrated in examples (5)-(6), simply constitutes the default case and does not need any extra explanation than economy. 
(17) English (Westergaard 2009b: 1028)

Why he can't hit? (Adam 3;4.01)

In Westergaard (2009a), such findings in child language are argued to be due to a principle of structural economy, formulated as in (18).

(18) Principle of structural economy

a. only build as much structure as there is evidence for in the input

b. only move elements as far as there is evidence for in the input

According to this economy principle, the verb in subject-initial declaratives such as (14) should only move to the position immediately above negation. This means that young Norwegian children who produce both (13) and (14) must assume that the target language has both V-(to-I-)to-C and V-to-I. If so, we would expect children to produce the word order V$\mathrm{Neg} / \mathrm{Adv}$ in all contexts. Since V2 word order will always mask V-to-I movement, evidence for this must be sought in contexts that do not require verb movement at all, e.g., embedded clauses and non-V2 wh-questions (which are grammatical in many Norwegian dialects, see e.g., Westergaard 2009c; Lohndal, Westergaard \& Vangsnes in press). Such examples are in fact relatively often found in child data of various languages, e.g., Swedish (Waldmann 2008), Swiss German (Schönenberger 2001), Faroese (Heycock, Sorace \& Hansen 2010) or Norwegian (Westergaard \& Bentzen 2007). Examples of non-target-consistent V-Neg/Adv word order in embedded clauses are illustrated in (19) and (20), from Norwegian and Swedish respectively, while (21) is an example from a non-V2 subject question in a Norwegian dialect.

(19) Norwegian (Westergaard 2009a: Ch. 9, example (50))

... at han skjønne ikke. (Ann 2;3.9)
that he understand.PRES not
'... that he doesn't understand.'
Target: ... at han ikke skjønne.


(20) Swedish (Waldmann 2008: 227)

ja ha en ny bil nä ni få inte mutsa ner.

I have a new car that you may not dirty down 'I have a new car that you may not make dirty.'

Target: jag har en ny bil som ni inte får smutsa ner.

(Waldmann 2008)

(21) Norwegian, Northern dialect (Westergaard \& Bentzen 2007, example (22))

kem som vil ikkje være ilag med han? (Ina, 3;1,8)

who that will not be together with him

'Who doesn't want to be with him?'

Target: kem som ikkje vil være i lag med han?

Our analysis of the child data leads to the conclusion that Norwegian children assume both verb movement to $\mathrm{C}$ (in non-subject-initial declaratives) and verb movement to I (in all clauses). Thus, verb movement in examples (13) and (14) targets different heads. This is arguably due to the economy principle operative in the acquisition process, making children avoid syntactic movement if there is no clear evidence in the input. Over the course of acquisition, children clearly unlearn V-to-I movement in contexts such as (19)-(21) where it is not found in the target language (which is a relatively drawn-out process, as backtracking is difficult in acquisition), but an important question is what they do in subject-initial declaratives: Do they eventually start moving the verb to $C$, or do they keep the original rule? In the next section we turn to data from other populations, suggesting that V-to-I movement is also found in the adult language.

\subsection{Second language (L2) acquisition}

Despite numerous claims within the Initial Hypothesis of Syntax that V2 word order would not transfer into an L2 (e.g., Platzack 2001), many studies have found evidence of considerable and relatively persistent V2 effects in the L2 (e.g., Robertson \& Sorace 1999; Westergaard 2003; Bohnacker 2006; Rankin 2012). An important finding is that subject-initial and non-subject-initial declaratives behave differently in this respect: In the acquisition of L2 English by Norwegian L1 learners, target-consistent non-V2 word order is in place relatively early in non-subject-initial 
declaratives, while V-Neg/Adv word order in subject-initial declaratives lasts considerably longer, often into a stage of near-nativeness. In a study of L2 English by L1 Norwegian 7-12-year-olds $(n=100)$, Westergaard (2003) finds that the 6th graders $(n=24)$ produced non-subject-initial declaratives with non-target-consistent V2, such as (22), 51\% of the time, while subject-initial declaratives with this word order (23) are significantly different, as they were produced as often as $83 \%$.

\section{(22) English}

*Every day plays John soccer. (49\% accuracy)

(23) *John plays always soccer. (17\% accuracy)

Similar evidence has been attested in an acceptability judgement task (using a Likert scale from 1 to 4 ) carried out with three age groups of L1 Norwegian learners of L2 English (9-10, 13-14 and 15-16, total n=67) (M. Jensen 2017, I. Jensen 2018). The findings show that there is a stable and significant difference between their judgements of subject- and nonsubject-initial declaratives $(p=.036)$ : While the difference in score between grammatical and ungrammatical non-subject-initial declaratives was around 1.6 in the oldest age group, it was only around 0.7 in the subjectinitial declaratives.

In our view, these findings indicate that in the process of learning L2 English, L1 speakers of Norwegian have to unlearn two verb movement rules, V-to-I-to-C and V-to-I. Unlearning one of them does not automatically lead to unlearning the other. For a number of reasons related to the frequency and salience of the relevant input, the unlearning of V-to-I will be harder and take longer.

\section{$3.3 \mathrm{~V} 2$ in heritage languages}

Research on heritage language bilinguals is a rapidly expanding field. A heritage language is typically defined as a language learned as a native language in a home environment, in a situation where this is not the majority language spoken in the larger community (e.g., Rothman 2009). As adults, heritage speakers are typically dominant in the majority language, which means that studying heritage languages could reveal what linguistic properties are vulnerable in a situation with reduced input and use. Germanic V2 languages have also been studied as heritage languages spoken in North America, e.g., Heritage Danish (Kühl \& Heegård Petersen 
2018); Heritage Norwegian (Johannessen 2015; Eide \& Hjelde 2015; Westergaard \& Lohndal 2019) or Heritage Icelandic (Arnbjörnsdóttir; Thráinsson \& Nowenstein 2018). These speakers are highly dominant in English, and it is expected that V2 in declaratives might be affected by the non-V2 word order of the majority language.

For Heritage Norwegian, Eide \& Hjelde (2015) point out a clear difference between the word order found in subject- and non-subject-initial declaratives. They investigated spontaneous production of one elderly speaker, who frequently violated V2 in the latter clause type (62\%), as illustrated in (24), while consistently producing V-Neg/Adv word order in the former clause type, as shown in (25). This indicates that subjectinitial and non-subject-initial declaratives are affected by cross-linguistic influence from English at largely different rates.

(24) Heritage Norwegian

* Og der dem lager vin. (Eide \& Hjelde 2015: 89)

and there they make wine

'And there they make wine.'

Target: Og der lager $\mathbf{d e}(\mathbf{m})$ vin.

(25) Heritage Norwegian

Nei, je visste itte henner. (Eide \& Hjelde 2015: 92)

No I knew not her

'No, I didn't know her.'

This discrepancy between subject-initial and non-subject-initial declaratives is also attested in a study of Heritage Icelandic by Arnbjörnsdóttir et al. (2018). The study included an acceptability judgement task carried out with 60 heritage speakers (age range 27-98). The findings show a large and significant difference between their judgements for the two types of structures, as they often accepted both V2 and non-V2 in non-subject-initial declaratives, such as (26), while they clearly preferred the V2 alternative in subject-initial declaratives, such as (27). Arnbjörnsdóttir et al. (2018: 404) conclude from this that "[v]iolations of the V2-constraint in topic-initial structures are much more common than violations of the V2-constraint in subject-initial clauses". 
(26) Heritage Icelandic (Arnbjörnsdóttir et al. 2018: 397)

Ámorgun sjáum við/við sjáum pað

Tomorrow see we/we see it

'Tomorrow we see it.'

(27) Heritage Icelandic (Arnbjörnsdóttir et al. 2018: 395)

Kristín talar stundum/stundum talar.

Kristin speaks sometimes/sometimes speaks

'Kristin sometimes speaks ..'

\subsection{Urban vernaculars/ethnolects}

The last few decades have seen a development of modern urban vernaculars (also called ethnolects) of several V2 languages, spoken by adolescents in multiethnic communities, see e.g., Wiese (2009); Opsahl \& Nistov (2010); Quist 2008) or Walkden (2017). A typical finding is that these varieties do not display consistent V2 word order, as illustrated in the following examples from Norwegian and German respectively:

(28) Norwegian urban vernacular (Freywald et al. 2015: 84) med limewire det tar én to dager with Limewire it takes one two days 'using Limewire it takes one or two days'

(29) German urban vernacular (Wiese 2009: 787)

$\begin{array}{llll}\text { Morgen } & \text { ich } & \text { geh } & \text { Arbeitsamt } \\ \text { tomorrow } & I & \text { go } & \text { job.center }\end{array}$

'Tomorrow I will go to the job center.'

Both examples (28) and (29) are non-subject-initial declaratives, where an adverbial is followed by the subject, resulting in non-V2 word order. Again, we find a sharp contrast between this clause type and subject-initial declaratives, where the literature does not document any lack of verb movement (across adverbs and negation) in the various urban vernaculars (see also Alexiadou \& Lohndal 2018 for further discussion).

To summarize this section, we have seen that subject-initial and non-subject-initial declaratives behave differently with respect to verb movement across a range of different populations: L1 children, L2 children/ adolescents, heritage speaker bilinguals as well as speakers of multi- 
ethnolects. The crucial point is that there is a distinction between the two, not necessarily the direction of the difference. We interpret these findings as support for an analysis where the two structures differ with respect to the position of the verb and argue that verb movement across the subject (in non-subject-initial declaratives) targets the $\mathrm{C}$ position, while verb movement across an adverb or negation (in subject-initial declaratives) only moves to the I position. In the next section, we turn to the issue of how this difference should be modeled syntactically.

\section{Discussion and conclusion}

On the view advanced here, the precise location to which the verb moves does not matter. Importantly, however, the economy principle operative in the acquisition process (cf. sections 2 and 3) requires that the child postulates movement only to a position for which there is evidence in the input. Based on the data reviewed, we see that different learner languages show that speakers distinguish between subject- and non-subject-initial clauses, a difference whose locus, we argue, is the placement of the verb. However, the data reviewed do not directly identify exactly what the landing sites in question are. Nevertheless, an advantage of this analysis is that the precise head hosting the verb may be different depending on the language or dialect in question, suggesting that languages are not identical in terms of which syntactic position the verb occupies in subject- and non-subjectinitial declaratives (cf. Mikkelsen 2015; Haegeman \& Greco 2018).

Related to the complex nature of the V2 phenomenon is the question of whether V2 is one big grammatical rule (or macro-parameter) or whether it is a collection of many smaller separate rules. We would argue that V2 needs to be decomposed in several ways, as also claimed in e.g., Weerman (1989); Westergaard (2008, 2009a; Migdalski (2010); Lohndal, Westergaard \& Vangsnes (in press). Arguments for this may also be found in models of L2 acquisition, as Amaral \& Roeper's (2014) multiple grammar approach (see also Roeper 1999) proposes that only non-complex rules may transfer from an L1 into an L2 (i.e. rules without exceptions or many sub-rules). Given data such as those provided in sections 3.2 and 3.3, this indicates that V2 is not a single overarching rule in languages like German and Norwegian, given that it indeed transfers, affecting different contexts for V2 differently. Thus, we argue that V2 word order is the result of a conspiracy of many smaller separate rules. For declarative clauses we then 
have two rules for verb movement, given in (30), which would account for the empirical patterns seen in section 3 .

a. V-to-I-to-C in non-subject-initial declaratives

b. V-to-I in subject-initial declaratives

We now consider some consequences of distinguishing subject-initial declaratives from non-subject-initial declaratives. Roberts (2004) argues for an analysis of V2 whereby a generalized EPP feature on the left peripheral head Fin is responsible for V2 word order. As a result of this feature, SpecFinP needs to be filled with a constituent: a phrase, a particle, or an expletive. This approach predicts that the verb moves to the same position in both subject- and non-subject-initial declaratives. A different analysis is pursued by Holmberg (2015). He defines V2 as in (31) (see also Alexiadou \& Anagnostopoulou 1998).

(31) a. A functional head in the left periphery attracts the finite verb

b. This functional head wants a constituent moved to its specifier position

As (31) makes clear, the functional head in question is not part of the definition. As such, this definition makes it possible that the functional head may differ across languages and varieties. It also makes it possible to argue that the finite verb moves to different positions and no single head is responsible as such for the V2 effect. Importantly, though, Holmberg's analysis does not extend to the crucial asymmetry between subject- and non-subject-initial declaratives discussed in this paper (see also Lohndal, Westergaard \& Vangsnes in press for other limitations when it comes to data from varieties of Norwegian). Rather, we need a more fine-grained system. The requisite granularity may be provided by the parameter hierarchy in Biberauer \& Roberts (2012) or the micro-cue model in Westergaard (2008, 2009a, b, c, 2014).

Biberauer \& Roberts (2012) suggest an account of variation across languages with respect to verb movement by way of a hierarchy of four levels: Macro-, meso-, micro-, and nano-parameters. In this model, V2 in English questions is considered a micro-parameter, since it applies at the level of a linguistic subcategory (auxiliaries), while V2 in a language 
like German would be a meso-parameter since it applies to the full verbal category. Crucially for Biberauer \& Roberts (2012), parameters are not innate; rather, they emerge in the course of acquisition.

Westergaard's (2008, 2009a, b, c, 2014) micro-cue model makes it possible to handle even more fine-grained variation, distinguishing between clause types, verb types, types of clause-initial element, etc. This model is inspired by Lightfoot's $(1999,2006)$ cue-based approach to acquisition and change. Lightfoot argues that a cue is a piece of syntactic structure provided by UG and triggered by relevant input. His cues are typically formulated in terms of major categories, such as the cue for V2 in (32).

\section{(32) Cue for V2 word order: ${ }_{\mathrm{CP}} \mathrm{XP}{ }_{\mathrm{C}} \mathrm{V}$... $]$}

The formulation in (32) simply says that the finite verb needs to appear in the C-position in all clause types. This means that Lightfoot's cue model is not sufficiently fine-grained to handle the variation we have argued for in this paper. Based on findings from acquisition, Westergaard (2008, 2009a, b, c, 2014) argues in favor of a micro-cue model, where the formulation of the micro-cues incorporates the relevant linguistic context. A few examples of the V2 variation found in Norwegian are provided in (33)-(35).

(33) Micro-cue for V2 in questions with long wh-elements:

$\left[\mathrm{IntP} \mathrm{XP}_{[+\mathrm{wh}] \mathrm{Int}^{\circ}} \mathrm{V}\right]$

(34) Micro-cue for V2 in questions with monosyllabic wh-elements: $\left[_{\text {IntP Int }}{ }^{\circ} w h\left[_{\text {TopP Top }^{\circ}} \mathrm{V} \mathrm{XP}_{[+\mathrm{FOC}]}\right]\right]$

(35) Micro-cue for word order in subject-initial declaratives with focussensitive adverbs: $\quad\left[{ }_{\text {DeclP }} X P\left[_{\text {FocP }}\right.\right.$ Foc-Adv Foc $\left.\left.[\mathrm{V}]\right]\right]$

A micro-cue, then, is a piece of abstract syntactic structure in a speaker's I-language grammar. Micro-cues are not provided by UG, but emerge as a result of an interaction of $\mathrm{UG}$, input and third factors in acquisition, such as economy. The structures in (3) and (4) above, repeated here for convenience, can also be thought of as micro-cues for subject- and nonsubject-initial declaratives, respectively. 
(3') Subject-initial declaratives:

$$
\left[{ }_{C P}\left[{ }_{C} C\right]\left[{ }_{I P} \text { subject }\left[{ }_{I} V\right]\left[{ }_{v P} t_{\text {subject }} t_{V} \ldots\right]\right]\right]
$$

(4') Non-subject-initial declaratives:

$$
\left[{ }_{\mathrm{CP}} \mathrm{XP}\left[{ }_{\mathrm{C}} \mathrm{V}\right]\left[_{\mathrm{IP}} \text { subject }\left[_{\mathrm{I}} \mathrm{t}_{\mathrm{V}}\right]\left[\mathrm{V}_{\mathrm{vP}} \mathrm{t}_{\text {subject }} \mathrm{t}_{\mathrm{V}} \ldots\right]\right]\right]
$$

In conclusion, we have argued in this paper that in order to fully understand the nature of Germanic V2 we need to analyze this linguistic phenomenon with an appropriately fine-grained grammar to deal with variation, including the difference between subject- and non-subjectinitial clauses. We contend that the asymmetric and symmetric analyses of declaratives may both be correct, in that languages may differ in this respect, depending on the possible evidence for verb movement in the input. Thus, we have argued that it is important to consider input data and evidence from learner languages in order to distinguish between the two analyses.

\section{References}

Ackema, Peter, Ad Neeleman \& Fred Weerman. 1993. Deriving functional projections. Proceedings of NELS 23. 17-31.

Alexiadou, Artemis \& Elena Anagnostopoulou. 1998. Parametrizing AGR: Word order, V-movement and EPP-checking. Natural Language \& Linguistic Theory 16. 491-539.

Alexiadou, Artemis, Elena Anagnostopoulou \& Florian Schäfer. 2015. External arguments in transitivity alternations. Oxford: Oxford University Press. doi:10.1093/acprof:oso/9780199571949.001.

Alexiadou, Artemis \& Terje Lohndal. 2018. V3 in Germanic: A comparison of urban vernaculars and heritage languages. Linguistische Berichte Sonderheft 25. 245-264.

Amaral, Luiz \& Tom Roeper. 2014. Multiple grammars and second language representation. Second Language Research 30. 3-36. doi:10.1177/0267658313519017.

Arnbjörnsdóttir, Birna, Höskuldur Thráinsson \& Iris Edda Nowenstein. V2 and V3 orders in North-American Icelandic. Journal of Language Contact 113. 379-412. 
Bentzen, Kristine. 2014. Verb placement in clauses with initial adverbial maybe. Nordic Atlas of Linguistic Structures (NALS). http://www.tekstlab.uio.no/ nals\#/chapter/17. doi:10.5617/nals.5390.

Biberauer, Theresa \& Ian Roberts. 2012. Towards a parameter hierarchy for auxiliaries: Diachronic considerations. Cambridge occasional papers in linguistics 6.9. 267-294.

Biberauer, Theresa \& Ian Roberts. 2015. The clausal hierarchy, features and parameters. In Ur Shlonsky (ed.), Beyond functional sequence: The cartography of syntactic structures 10, 295-313. Oxford: Oxford University Press. doi:10.1093/acprof:oso/9780190210588.003.0016.

Bierwisch, Manfred. 1963. Grammatik des deutschen Verbs. Berlin: Akademie-Verlag.

Bohnacker, Ute. 2006. When Swedes begin to learn German: From V2 to V2. Second Language Research 22(4). 443-486. doi:10.1191/0267658306sr275oa.

Branigan, Philip. 1996. Verb-second and the A-bar status of subjects. Studia Linguistica 50. 50-79.

Bury, Dirk. 2000. Effects of self-attachment and the status of functional projections. Snippets 2. 8-10.

Cinque, Guglielmo. 1999. Adverbs and functional heads. Oxford: Oxford University Press.

Clahsen, Harald. 1986. Verb inflections in German child language: acquisition of agreement markings and the functions they encode. Linguistics 24. 79-121. doi:10.1515/ling.1986.24.1.79.

Craenenbroeck, Jeroen van \& Liliane Haegeman. 2007. The derivation of subjectinitial V2. Linguistic Inquiry 38. 167-178. doi:10.1162/ling.2007.38.1.167.

Den Besten, Hans. 1983. On the interaction of root transformations and lexical deletive rules. In Werner Abraham (ed.), On the formal syntax of the Westgermania, 47-131. Amsterdam: John Benjamins. doi:10.1075/la.3.03bes.

Diesing, Molly. 1990. Verb movement and subject position in Yiddish. Natural Language and Linguistic Theory 8. 41-79. doi:10.1007/BF00205531.

Eide, Kristin \& Arnstein Hjelde. 2015. Verb Second and finiteness morphology in Norwegian heritage language of the American Midwest. In B. R. Page \& Mike Putnam (eds.), Moribund Germanic Heritage Languages in North America, 64-101. Leiden: Brill. doi:10.1163/9789004290211_005.

Fanselow, Gisbert. 2001. Features, theta-roles, and free constituent order. Linguistic Inquiry 32. 405-436.

Fanselow, Gisbert. 2004. Münchhausen-style head movement and the analysis of verb second. In Ralf Vogel (ed.), Linguistics in Potsdam 22, 9-49. Potsdam: University of Potsdam.

Fanselow, Gisbert. 2009. Bootstrapping verb movement and the clausal architecture of German (and other languages). In Artemis Alexiadou, Jorge Hankamer, Thomas McFadden, Justin Nuger \& Florian Schäfer (eds.), Advances in comparative Germanic syntax, 85-118. Amsterdam: John Benjamins. doi:10.1075/la.141.05boo. 
Freywald, Ulrike, Leonie Cornips, Ganuza, Natalia, Ingvild Nistov \& Toril Opsahl. 2015. Beyond verb second - a matter of novel information-structural effects? Evidence from Norwegian, Swedish, German and Dutch. In Jacomine Nortier \& Bente A. Svendsen (eds.), Language, youth and identity in the 21st century: Linguistic practices across urban spaces, 73-92. Cambridge: Cambridge University Press. doi:10.1017/CBO9781139061896.006.

Grohmann, Kleanthes K. 2003. Prolific domains. Amsterdam: John Benjamins. doi:10.1075/la.66.

Haegeman, Liliane. 1986. INFL, COMP and nominative Case assignment in Flemish infinitivals. In Henk van Riemsdijk \& Pieter Muysken (eds.), Features and Projections, 123-137. Dordrecht: Foris.

Haegeman, Liliane. 1996. Verb second, the split CP and initial null subjects in early Dutch finite clauses. Geneva Generative Papers 4. 133-175.

Haegeman, Liliane \& Ciro Greco. 2018. West Flemish V3 and the interaction of syntax and discourse. Journal of Comparative Germanic Linguistics 21. 1-56. doi:10.1007/s10828-018-9093-9.

Haider, Hubert. 1988. Theta-tracking systems - evidence from German. In Laszlo Marácz \& Pieter Muysken (eds.), Configurationality, 185-206. Dordrecht: Foris.

Holmberg, Anders. 1986. Word order and syntactic features in the Scandinavian languages and English. Doctoral dissertation, Stockholm University.

Holmberg, Anders. 2015. Verb second. In Tibor Kiss \& Artemis Alexiadou (eds.), Syntax - Theory and Analysis. An International Handbook, 342-383. Berlin: Mouton de Gruyter.

Holmberg, Anders \& Christer Platzack. 1995. The role of inflection in Scandinavian syntax. Oxford: Oxford University Press. doi:10.1515/9783110847277.93 .

Hrafnbjargarson, Gunnar Hrafn, Kristine Bentzen \& Anna-Lena Wiklund. 2010. Observations on extraction from V2 clauses in Scandinavian. Nordic Journal of Linguistics 33.3. 299-309. doi:10.1017/S0332586510000223.

Hsu, Brian. 2016. Syntax-prosody interactions in the clausal domain: Head movement and Coalescence. Doctoral dissertation, University of Southern California.

Jensen, Miriam. 2017. Investigating the bottleneck hypothesis in Second Language acquisition: The acquisition of narrow syntax and functional morphology among Norwegian L2 learners of English. MA Thesis, UiT The Arctic University of Norway, Norway.

Johannessen, Janne B. 2015. The corpus of American Norwegian speech (CANS). In Beáta Megyesi (ed.), Proceedings of the 20th Nordic Conference of ComputaNonal LinguisNcs, NODALIDA 2015. NEALT Proceedings Series 23. Jordens, Peter. 1990. The acquisition of verb placement in Dutch and German. Linguistics 28. 1407-1448. doi:10.1515/ling.1990.28.6.1407. 
Koeneman, Olaf. 1995. Flexible phrase structure: On the role of verbal projections in Dutch, English and Yiddish. MA dissertation, Utrecht University.

Koeneman 2000. The flexible nature of verb movement. Doctoral dissertation, Utrecht University.

Koopman, Hilda. 1984. The syntax of verbs. Dordrecht: Foris.

Kühl, Karoline \& Jan Heegård Petersen. 2018. Word order in American Danish declaratives with a non-subject initial constituent. Journal of Language Contact 11.3. 413-440.

Lightfoot, David. 1999. The development of language: Acquisition, change, and evolution. Wiley-Blackwell.

Lightfoot, David. 2006. How new languages emerge. Cambridge: Cambridge University Press. doi:10.1017/CBO9780511616204.

Lohndal, Terje. 2010. Medial-wh phenomena, parallel movement, and parameters. Linguistic Analysis 34. 215-244. doi:10.4324/9781315267050-6.

Lohndal, Terje. 2014. Phrase structure and argument structure. Oxford: Oxford University Press.

Lohndal, Terje, Marit Westergaard \& Øystein Vangsnes. In press. Verb second in Norwegian: Variation and Acquisition. In Rebecca Woods \& Sam Wolfe (eds.), Rethinking V2. Oxford: Oxford University Press.

Migdalski, Krzysztof. 2010. On the relation between V2 and the second position cliticization. Lingua 120(2). 329-353. doi:10.1016/j.lingua.2008.05.005.

Mikkelsen, Line. 2015. VP anaphora and verb-second order in Danish. Journal of Linguistics 51. 595-643. doi: 10.1017/S0022226715000055.

Müller, Gereon. 2004. Verb-second as vP-first. Journal of Comparative Germanic Linguistics 7. 179-234.

Müller, Gereon \& Wolfgang Sternefeld. 1993. Improper movement and unambiguous binding. Linguistic Inquiry 24. 461-507.

Nilsen, Øystein. 2003. Eliminating Positions. Doctoral dissertation, University of Utrecht.

Opsahl, Toril \& Ingvild Nistov. 2010. On some structural aspects of Norwegian spoken among adolescents in multilingual settings in Oslo. In Pia Quist \& Bente Ailin Svendsen (eds.), Multilingual urban Scandinavia: New linguistic practices, 49-63. Bristol: Multilingual Matters. doi:10.21832/9781847693143009.

Platzack, Christer. 1998. A visibility condition for the C-domain. Working Papers in Scandinavian Syntax 61. 53-99.

Platzack, Christer. 2001. The vulnerable C-domain. Brain and Language 77. 364 377. doi:10.1006/brln.2000.2408.

Poeppel, David \& Ken Wexler. 1993. The full competence hypothesis of clause structure in early German. Language 69. 1-33. doi:10.2307/416414.

Postma, Gertjan. 2011. Modifying the hearer. The nature of the left periphery of main clauses in Frisian and Dutch. Paper presented at CGSW 26, Meertens Institute, Amsterdam, June 23-24. 
Quist, Pia. 2008. Sociolinguistic approaches to multiethnolect: Language variety and stylistic practice. International Journal of Bilingualism 12(1-2). 43-61. doi:10.1177/13670069080120010401.

Rögnvaldsson, Eirikur \& Höskuldur Thráinsson. 1990. On Icelandic word order once more. In Joan Maling \& Annie Zaenen (eds.), Syntax and semantics 24: Modern Icelandic syntax, 3-40. New York: Academic Press.

Rankin, Tom. 2012. The transfer of V2: Inversion and negation in German and Dutch learners of English. International Journal of Bilingualism 16. 139-58. doi:10.1177/1367006911405578.

Rizzi, Luigi. 1997. The fine structure of the left periphery. In Liliane Haegeman (ed.), Elements of grammar: A handbook of generative syntax, 281-337. Dordrecht: Kluwer.

Roberts, Ian. 2004. The C-system in Brythonic Celtic languages, V2, and the EPP. In Luigi Rizzi (ed.), The structure of CP and IP: The cartography of syntactic structures 2, 297-327. Oxford: Oxford University Press.

Roberts, Ian. 2007. Diachronic syntax. Oxford: Oxford University Press.

Robertson, Daniel \& Antonella Sorace. 1999. Losing the V2 Constraint. In Elaine C. Klein \& Gita Martohardjono (eds.), The development of second language grammars: A generative approach, 317-61. Amsterdam: John Benjamins. doi:10.1075/lald.18.16rob.

Roeper, Tom. 1999. Universal bilingualism. Bilingualism: Language and Cognition 2. 169-186. doi:10.1017/S1366728999000310.

Rothman, Jason. 2009. Understanding the nature and outcomes of early bilingualism: Romance languages as heritage languages. International Journal of Bilingualism 13.2. 155-163. doi:10.1177/1367006909339814.

Santelmann, Lynn. 1995. The acquisition of verb second grammar in child Swedish: Continuity of Universal Grammar in WH-questions, topicalizations and verb raising. Doctoral dissertation, Cornell University.

Schwartz, Bonnie D. \& Sten Vikner. 1989. All verb second clauses are CPs. Working Papers in Scandinavian Syntax 43. 27-49.

Schwartz, Bonnie D. \& Sten Vikner. 1996. The verb always leaves IP in V2 clauses. In Adriana Belletti \& Luigi Rizzi (eds.), Parameters and functional heads, 11-62. Oxford: Oxford University Press.

Sells, Peter. 2001. Structure, alignment, and optimality in Swedish. Stanford, CA: CSLI.

Shlonsky, Ur. 1994. Agreement in comp. The Linguistic Review 11. 351-375. doi:10.1515/tlir.1994.11.3-4.351.

Snyder, William. 2007. Child language: The parametric approach. Oxford: Oxford University Press.

Taraldsen, Knut Tarald. 1986. On verb second and the functional content of syntactic categories. In Hubert Haider \& Martin Prinzhorn (eds.), Verb second phenomena in Germanic languages, 7-25. Dordrecht: Foris. doi:10.1515/9783110846072.7. 
Thiersch, Craig. 1978. Topics in German syntax. Doctoral dissertation, MIT. Thornton, Rosalind. 1990. Adventures in long-distance moving: The acquisition of complex wh-questions. Doctoral dissertation, University of Connecticut.

Tomaselli, Alessandra. 1990. COMP ${ }^{0}$ as a licensing head: An argument based on cliticization. In Joan Mascaró \& Marina Nespor (eds.), Grammar in progress. GLOW essays for Henk van Riemsdijk, 433-445. Dordrecht: Foris.

Travis, Lisa. 1984. Parameters and effects of word order variation. Doctoral dissertation, MIT.

Travis, Lisa. 1991. Parameters of phrase structure and verb-second phenomena. In Robert Freidin (ed.), Principles and parameters in comparative grammar, 339-364. Cambridge, MA: MIT Press.

Vikner, Sten. 1995. Verb movement and expletive subjects in the Germanic languages. Oxford: Oxford University Press.

Waldmann, Christian. 2008. Input och output: Ordföljd i svenska barns huvudsatser och bisatser. [Input and output: Word order in Swedish children's main and embedded clauses]. Doctoral dissertation, University of Lund.

Waldmann, Christian. 2012. Moving in small steps towards verb second: A case study. Nordic Journal of Linguistics 34(3). 331-359. doi:10.1017/ S0332586512000054.

Walkden, George. 2017. Language contact and V3 in Germanic varieties new and old. The Journal of Comparative Germanic Linguistics 20(1). 49-81. doi:10.1007/s10828-017-9084-2.

Weerman, Fred. 1989. The V2 conspiracy. A synchronic and diachronic analysis of verbal positions in Germanic languages. Berlin: Walter de Gruyter.

Westergaard, Marit R. 2003. Unlearning V2: Transfer, markedness, and the importance of input cues in the acquisition of word order in English by Norwegian children. EUROSLA Yearbook 3. 77-101. doi:10.1075/eurosla.3.07wes.

Westergaard, Marit R. 2004. The interaction of input and UG in the acquisition of verb movement in a dialect of Norwegian. Nordlyd 32(1). 110-134. doi: $10.7557 / 12.61$.

Westergaard, Marit. 2008. Acquisition and change: On the robustness of the triggering experience for word order cues. Lingua 118. 1841-1863. doi:10.1016/j. lingua.2008.05.003.

Westergaard, Marit. 2009a. The acquisition of word order: Micro-cues, information structure, and economy. Amsterdam: John Benjamins Publishing. doi:10.1075/ la.145.

Westergaard, Marit. 2009b. Usage-based vs. rule-based learning: the acquisition of word order in wh-questions in English and Norwegian. Journal of Child Language 36. 1023-1051. doi:10.1017/S0305000909009349.

Westergaard, Marit. 2009c. Microvariation as Diachrony: A View from Acquisition. Journal of Comparative Germanic Linguistics 12(1). 49-79. doi:10.1007/ s10828-009-9025-9. 
Westergaard, Marit. 2014. Linguistic variation and micro-cues in first language acquisition. Linguistic Variation 14. 26-45.

Westergaard, Marit \& Kristine Bentzen. 2007. The (non-) effect of input frequency on the acquisition of word order in Norwegian embedded clauses. In Insa Gülzow \& Natalia Gagarina (eds.), Frequency effects in language acquisition: Defining the limits of frequency as an explanatory concept (Studies on Language Acquisition), 271-306. Berlin/New York: Mouton de Gruyter. doi:10.1515/9783110977905.271.

Westergaard, Marit \& Terje Lohndal. 2019. Verb second word order in Norwegian heritage language: Syntax and pragmatics. In David Lightfoot \& Jon Havenhill (eds.), Variable properties in language: Their nature and acquisition, 91-102. Washington, DC: Georgetown University Press. doi:10.2307/j.ctvfxv99p.12.

Wiese, Heike. 2009. Grammatical innovation in multiethnic urban Europe: New linguistic practices among adolescents. Lingua 119.5 . 782-806. doi:10.1016/j. lingua.2008.11.002.

Wiklund,Anna-Lena, Kristine Bentzen, GunnarHrafn Hrafnbjargarson \& Thorbjörg Hróarsdóttir. 2009. On the distribution and illocution of V2 in Scandinavian that-clauses. Lingua 119. 1914-1938. .doi:10.1016/j.lingua.2009.03.006.

Zwart, Jan-Wouter. 1993. Dutch syntax: a minimalist approach. Doctoral dissertation, University of Groningen.

Zwart, Jan-Wouter. 1997. The morphosyntax of verb movement: A minimalist approach to Dutch syntax. Dordrecht: Kluwer. 